\title{
Do pollinators respond in a dose-dependent manner to flower herbivory?: An experimental assessment in Loasa tricolor (Loasaceae)
}

\section{¿Responden los polinizadores en forma dosis-dependiente a la herbivoría floral?: Una evaluación experimental en Loasa tricolor (Loasaceae)}

\author{
Roxana Cares-Suárez ${ }^{*}$, Tomás Poch, Romina F. Acevedo, Ignacio Acosta-Bravo, Carolina \\ Pimentel, Claudia Espinoza, Rocio A. Cares, Paola Muñoz, Alejandra V. González \& Carezza \\ BOTTO-MAHAN
}

Departamento de Ciencias Ecológicas, Facultad de Ciencias, Universidad de Chile, PO Box 653, Santiago, Chile.

*r.cares.suarez@gmail.com

\begin{abstract}
Pollinators are able to discriminate among different floral phenotypes. Thus, flowers more attractive to pollinators usually receive more visits to their reproductive structures. However, this effect of attraction does not necessarily occur in a binary way, all-or-nothing. Loasa tricolor KerGawl. is an annual herb covered with stinging hairs. Flowers present a corolla with five yellow petals and red nectarine scales. In this study, we assess whether the variation in the floral phenotype of $L$. tricolor affects discrimination by pollinators, following a dose-dependent type of response. This study was carried out in a protected area of Chile where L. tricolor shows high levels of florivory, probably affecting its attraction to pollinators. We experimentally modified the corolla phenotype, removing three or all petals. We measured visitation rate, richness and diversity of pollinator species in treated and control flowers. Results show that three-petal-removal did not reduce the visitation rate compared to control, while complete-petal-removal significantly reduced the visitation rate. Most pollinator species were recorded in the three-petal-removal treatment (nine species), while complete-petal-removal treatment obtained the lowest richness value (four species). These results suggest that species diversity, richness and visitation rates are affected by flower phenotype variation, but probably for complete petal loss only. We suggest that different levels of florivory on $L$. tricolor do not affect pollinator discrimination in a dose-dependent way.
\end{abstract}

KEYwORDS: Flower herbivory, pollination, visitation rate, florivory.

\section{RESUMEN}

Los polinizadores son capaces de discriminar entre diferentes fenotipos florales. Por lo tanto, flores más atractivas para los polinizadores usualmente reciben más visitas a sus estructuras reproductivas. Sin embargo, este efecto de atracción no ocurre necesariamente de una forma binaria, todo o nada. Loasa tricolor KerGawl. es una hierba anual cubierta con pelos urticantes. Sus flores presentan una corola con cinco pétalos amarillos y escamas nectarinas rojas. En este estudio, evaluamos si la variación en el fenotipo floral de L. tricolor afecta la discriminación por polinizadores, siguiendo una respuesta de tipo dosis-dependiente. Este estudio fue llevado a cabo en un área protegida de Chile donde L. tricolor muestra altos niveles de herbivoría floral, probablemente afectando su atracción hacia los polinizadores. Modificamos experimentalmente el fenotipo de la corola, removiendo tres o todos sus pétalos. Medimos la tasa de visita, riqueza y diversidad de especies de polinizadores en las flores tratadas y control. Nuestros resultados muestran que la remoción de tres pétalos no reduce la tasa de visita comparado con el control, mientras que la remoción de todos los pétalos reduce significativamente la tasa de visita. La mayoría de las especies de polinizadores fueron registradas en el tratamiento de remoción de tres pétalos (nueve especies), mientras que en el tratamiento de remoción de todos los pétalos se obtuvo un bajo valor de riqueza (cuatro especies). Estos resultados sugieren que la diversidad, riqueza y tasa de visita de las especies son afectadas por la variación en el fenotipo floral, pero probablemente sólo por la pérdida completa de pétalos. Nosotros sugerimos que los diferentes niveles de herbivoría floral en $L$. tricolor no afectan la discriminación de los polinizadores en forma dosis-dependiente.

Palabras Clave: Herbivoría floral, polinización, tasa de visita, florivoría. 


\section{INTRODUCTION}

Pollination by insects or other animals is one of the fundamental ecological and evolutionary processes to maintain the viability and diversity of angiosperms (Medel \& Nattero 2009). This is mainly because pollinators can exert selective pressures since they are able to discriminate on some phenotypic and life history traits such as number of flowers, flowering time, symmetry, scent, color, size and shape of the flower, nectar production, as well as the number and size of pollen (Strauss et al.1996, Faegri \& Van der Pijl 1979, Morgan \& Conner 2001).

The pollinator service can be altered when external agents modify these floral attributes (Strauss 1997). Herbivores are an example of these agents (Strauss et al. 1996, Lehtila \& Strauss 1997), as they can reduce the reproductive success of plant species by damaging the flower structure (Krupnick et al. 1999), which means they can also exert selective pressure on plants (Marquis 1992). Depending on the nature of damage, the impact in the reproduction process can be direct, because of the loss of gametes (Krupnick \& Weiss 1999), or indirect, by reduction in the rate of visits by insects or other animal pollinators (Strauss et al. 1996). This indirect effect may be due to a degradation of floral appearance, loss of symmetry, reduction in the quantity or quality of nectar or decrease in the number of flowers per display (Krupnick \& Weis 1999, Krupnick et al. 1999, Aizen \& Raffaele 1996). There are cases in which flowers have developed specialized structures for pollinator-flower interaction such as nectar guides, landing petals and a differentiated petal color. Studies have shown that damage on these structures decrease the rate of visits from pollinators (Botto \& Ojeda 2000). Since pollination and herbivory operate simultaneously (Strauss \& Armbruster 1997), many plant traits might have evolved as a result of opposing selective pressures acting among them (Strauss 1997, Galen \& Cuba 2001).

Loasa tricolor KerGawl. (Loasaceae) is an annual herb covered with stinging hairs. Its flowers have a corolla of five yellow petals and red nectarines scales (Hoffmann 1998). Flowers of this species can show high levels of herbivory modifying their floral phenotype and probably affecting their attraction to pollinators. In this context, the aim of this study is to assess whether the variation in floral phenotype of $L$. tricolor affects discrimination by pollinators, following a dose-dependent type of response. We hypothesized that the visit of pollinators is negatively affected with increasing levels of damage on the corolla.

\section{METHODS}

STUDY SITE AND NATURAL HISTORY

The fieldwork was conducted on November of 2009 and
2010, at the Reserva Nacional Río Clarillo ( $33^{\circ} 51^{\prime} \mathrm{S}, 70^{\circ}$ $29^{\prime} \mathrm{W}$ ), located about $50 \mathrm{~km}$ SE from Santiago, Chile. The Reserve comprehends an area of 13,085 ha, with heights ranging from 850 to $3,057 \mathrm{~m}$ a.s.l., characterized by a subandean-mediterranean climate (di Castri 1968). Vegetation comprises Mediterranean Andean sclerophyllous forest as Quillaja saponaria Molina and Lithrea caustica (Molina) Hook. et Arn. (Luebert \& Pliscoff 2006). In the study site, L. tricolor grows mainly in conditions of light exposure or underneath vegetation that includes species such as $L$. caustica. The flowering season extends from August to March (Hoffmann 1998).

\section{FLOWER HERBIVORY}

To estimate flower herbivory in the focal population, we randomly sampled 80 plants with flowers in anthesis. We quantified the total number of flowers and the number of damaged ones.

\section{EXPERIMENTAL PROCEDURE}

To determine whether the variation on the floral phenotype of $L$. tricolor affect discrimination by pollinators, we randomly assigned 88 mono-specific patches of $1 \mathrm{~m}^{2}$ each, with approximately $10 \mathrm{~L}$. tricolor's flowers per patch, to one of the following treatments: (i) control flowers $(\mathrm{C} ; \mathrm{N}$ $=310$ flowers in 28 patches), consisting in flowers with no petal removal, (ii) three-petal-removal flowers ( $\mathrm{T} 1 ; \mathrm{N}=$ 300 flowers in 28 patches) obtained by manually removing three petals and leaving the two remaining in opposite sides, and (iii) all-petal-removal flowers (T2, $\mathrm{N}=320$ flowers in 30 patches), also obtained by manual removal (Fig. 1). Treatments kept flower symmetry constant.

For each focal flower, we observed pollinator visits for $10 \mathrm{~min}$. A visitor was considered a pollinator when the flower reproductive structures were contacted by the visitor. Recordings were performed only under sunny conditions between 0900 and 1700 by six trained observers. The unknown pollinators were captured and sacrificed for taxonomic identification.

\section{Statistical ANALYSIS}

We compared pollinator diversity by estimating richness Sobs (Mao Tao) and diversity $H^{\prime}$ (Shannon-Wiener index) (Gotelli \& Colwell 2001, Gómez \& Perfectti 2009). Both indices were calculated within $95 \%$ confidence intervals, obtained after 500 runs and randomize samples with replacement, using EstimateS software version 8.2.0 (Colwell 2009). Data were analyzed by paired $t$-test with Bonferroni's adjustments (Sokal \& Rohlf 1995). Data did not show normal distribution, therefore, differences among treatments were tested with a nonparametric Kruskal-Wallis ANOVA and multiple a posteriori comparisons (Sokal \& Rohlf 1995). 

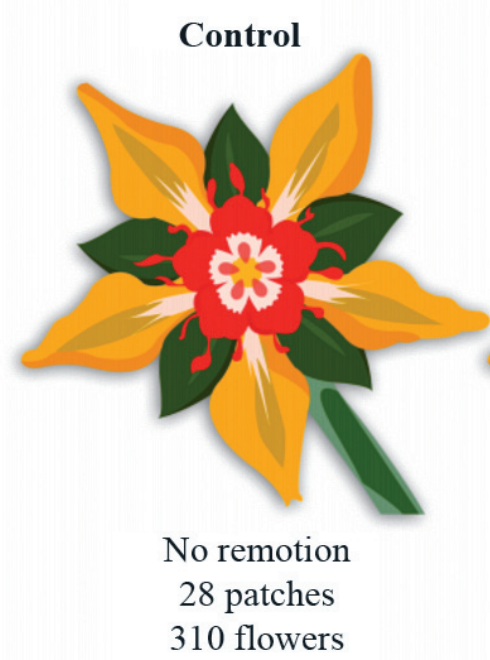

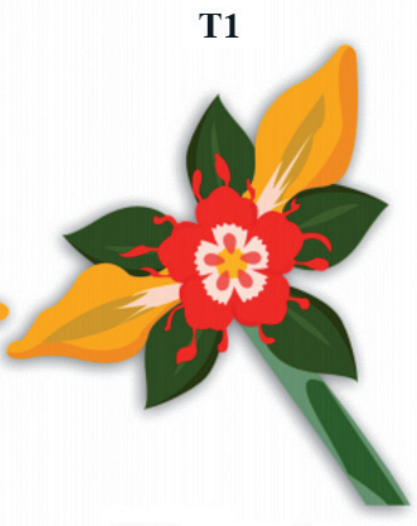

$60 \%$ removal

28 patches

300 flowers

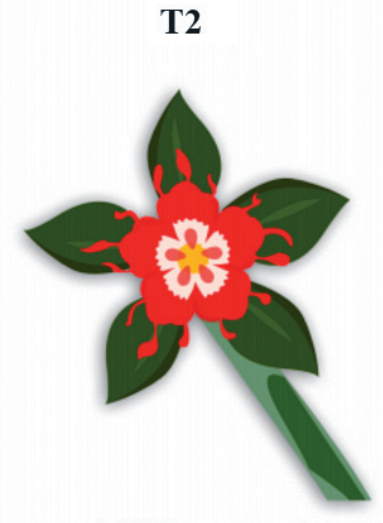

$100 \%$ removal
30 patches
320 flowers

FIGURE 1. Experimental treatments applied to flowers of L. tricolor. The number of patches and flowers for each treatment are shown.

FIgURA 1. Tratamientos experimentales aplicados a L. tricolor. Se muestra el número de parches y flores utilizados en cada tratamiento.

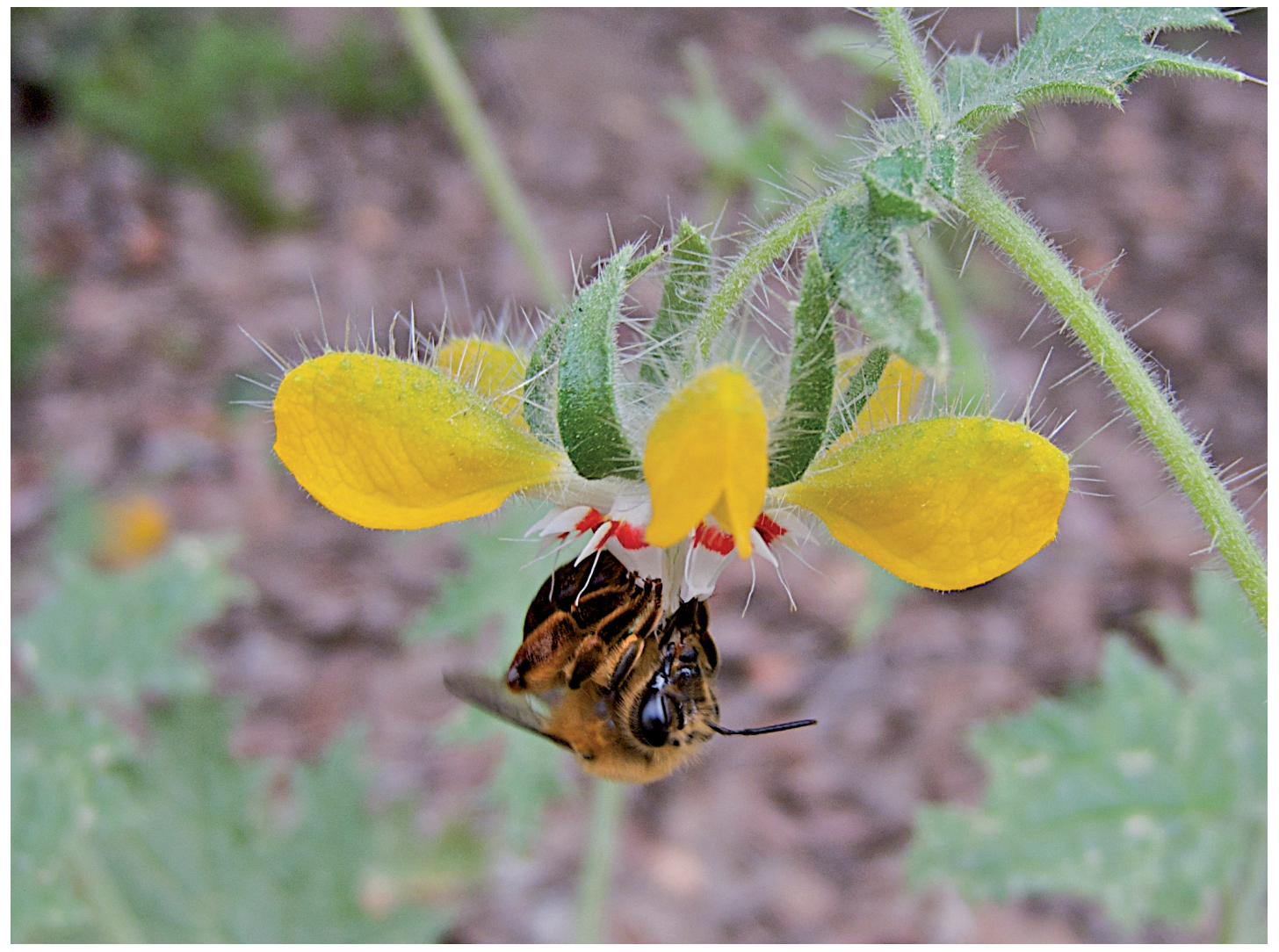

FIgURE 2. The hymenopteran Cadeguala occidentalis visiting L. tricolor.

FIGURA 2. El himenóptero Cadeguala occidentalis visitando L. tricolor. 


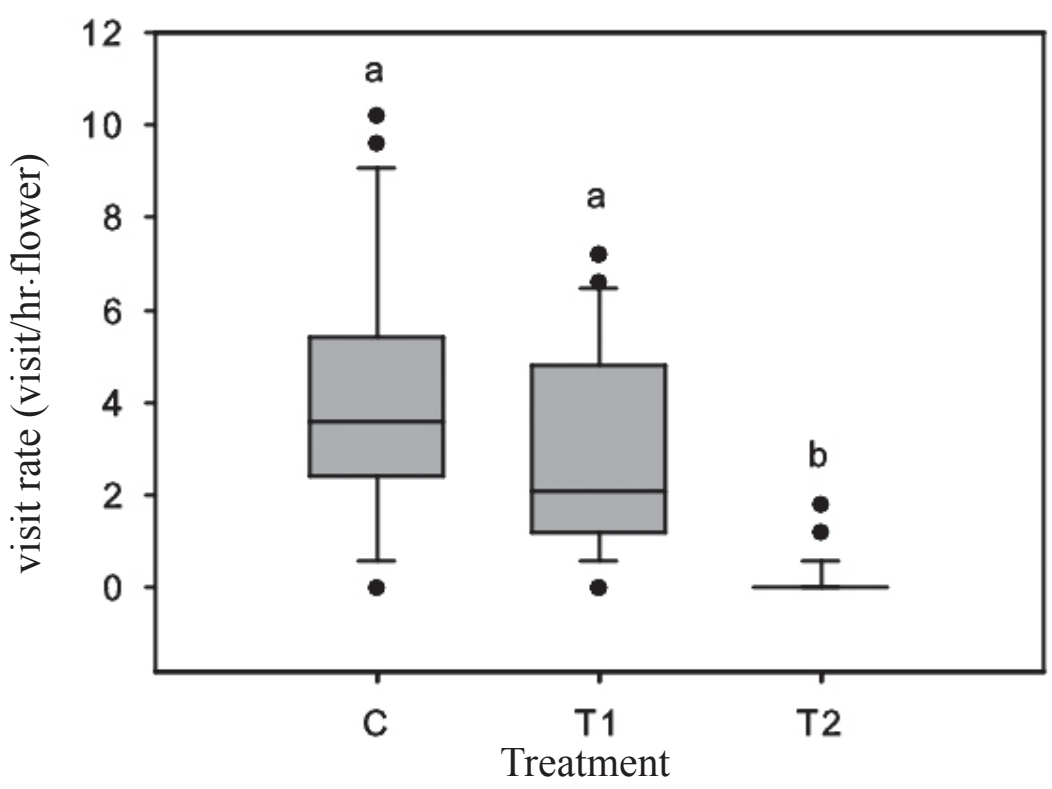

Figure 3. Pollinator visit rate (visit/hr-flower) for each treatment (median and inter-quartile range), $\mathrm{H}_{2}=51.87 ; \mathrm{N}=88 ; P<0.0001$. Different letters show significant differences between treatments, $P<0.001$ (Bonferroni adjustment, $\alpha=0.017$ ).

Figura 3. Tasa de visita de los polinizadores (visita/hr-flor) para cada tratamiento (mediana y rango intercuartil), $\mathrm{H}_{2}=51,869 ; \mathrm{N}=88 ; P<$ 0,0001. Letras diferentes indican diferencias significativas entre tratamientos, $P<0,001$ (ajuste de Bonferroni, $\alpha=0,017$ ).

TABLE I. Visit proportion of pollinator species recorded for L. tricolor (control and treatments combined).

TABLA I. Proporción de visita de las especies polinizadoras registradas para L. tricolor (control y tratamientos combinados).

\begin{tabular}{cll}
\hline \multicolumn{1}{c}{ Pollinator SPECIES } & Families & Visit PROPORTION \\
\hline Hymenoptera & & \\
\hline Cadeguala occidentalis & Colletidae & 0.510 \\
\hline Caupolicana hirsuta & Colletidae & 0.137 \\
\hline Colletes cyanescens & Colletidae & 0.036 \\
\hline Ruizantheda sp. & Halictidae & 0.174 \\
\hline Corynura chloris & Halictidae & 0.075 \\
\hline Anthidium chilense & Megachilidae & 0.008 \\
\hline Manuelia sp. & Apidae & 0.005 \\
\hline Diptera & & 0.003 \\
\hline Sirfido sp. & Syrphidae & 0.052 \\
\hline Two unidentified spp. & & \\
\hline
\end{tabular}




\section{RESULTS}

We found that $63.75 \%$ of the sampled plants $(\mathrm{N}=80)$ had some level of floral damage, including partial florivory or complete petal loss. The mean number of flowers per plant $( \pm \mathrm{SE})$ was $4.24 \pm 0.41$, with an average $( \pm \mathrm{SE})$ of $1.18 \pm$ 0.15 flowers with some level of florivory. Overall, $27.73 \%$ of the total sampled flowers $(\mathrm{N}=339)$ showed some level of damage. According to the type of damage (from small bites to a complete petal removal), the most probable herbivore species are Lepidoptera and Coleoptera larvae.

The recorded pollinators for $L$. tricolor are shown in Table I. A total of 10 pollinator species were recorded for this plant, being the control (C) and the three-petalremoval (T1) treatments the ones with higher species richness (9 spp.). The complete-petal-removal treatment (T2) was visited by only four hymenopteran species. The hymenopteran Cadeguala occidentalis was the most frequent pollinator representing $51 \%$ of the total visits $(\mathrm{N}$ $=386$, Fig. 2), followed by Ruizantheda $s p$. (17.4\%) and Caupolicana hirsuta (13.7\%) (Table I). Pollinator species richness was significantly different only between $\mathrm{T} 2$ and $\mathrm{C}$ $(t=3.32$, d.f. $=20, P=0.003$; EstimateS, 500 iterations; Bonferroni adjustment $(\alpha=0.017))$. Similarly, statistical analyses comparing species diversity among treatments showed marginally significant differences between $\mathrm{T} 2$ and $\mathrm{C}(t=2.45$, d.f. $=20, P=0.024$; EstimateS, 500 iterations; Bonferroni adjustment $(\alpha=0.017)$ ).

Floral damage generated by petal removal negatively affected the rate of pollinator visits (mean (visit/hr-flower) $\pm \mathrm{SE}: \mathrm{C}=4.20 \pm 2.92 ; \mathrm{T} 1=2.96 \pm 2.16 ; \mathrm{T} 2=0.14 \pm 0.41)$. Significant differences were found in pollinator visit rates depending on the treatment applied $\left(\mathrm{H}_{2}=51.87 ; \mathrm{N}=88 ; P\right.$ $<0.0001)$. A posteriori comparisons revealed that $\mathrm{T} 2$ differs from the control and T1 (Fig. 3).

\section{DISCUSSION}

In this study we examine the effect of floral damage, through the experimental removal of petals on pollinator attraction in the native herb L. tricolor. Our results suggest that the presence of petals is an absolutely necessary trait for the reproductive success of this herb, playing an important role on floral species recognition by potential pollinators.

The focal population of L. tricolor shows a high degree of floral herbivory, which means that flowers are naturally subject to floral area loss. This damage, which is produced directly in the corolla, altering their floral phenotype, reduces the attractiveness of flowers to pollinators (Karban \& Strauss 1993). Despite this, our results indicate that, apparently, pollinators visit partially damaged flowers of $L$. tricolor with the same frequency as they visit un-manipulated flowers (control flowers). But the service of pollination is considerably reduced in flowers without petals. According to this, the removal of petals does not appear to follow a dose-dependent response by pollinators, but rather an allor-nothing response. However, we cannot completely rule out that two petals are a display-threshold for pollinators to make a foraging decision, implying that one petal could be enough to capture the interest of pollinators. Future studies could assess how is rate of pollination affected by more than two levels of damage, as well as loss of floral symmetry.

Manipulative field experiments indicate that the complete removal of petals (T2) had a strong impact on pollinator attraction, reducing the number of visiting species (richness and diversity) and their frequency (rate of visits) in comparison to control flowers (C). The pollinator species more affected by the total loss of petals were the hymenopterans $C$. occidentales, Ruizantheda sp., C. hirsuta and $C$. chloris. Petals form part of the searching image of pollinators, which are able to discriminate between intact and completely damaged flowers. In fact, several studies have shown that pollinators avoid visiting damaged flowers (e.g., Murawski 1987, Karban \& Strauss 1993, Krupnick et al. 1999, Mothershead \& Marquis 2000, Leavitt \& Robertson 2006, Sánchez-Lafuente 2007). Probably, the light reflected by the petals may attract some pollinator species, and in fact, several studies have shown the importance of visual recognition by insect pollinators (Vorobyev et al. 2001, Dyer \& Chittka 2004a, 2004b). Besides this, we cannot rule out that chemical compounds in the removed petals act as an additional attraction factor (Raguso \& Pichersky 1995, Dudareva et al. 1998).

Future work might be concentrated in understanding the role of chemical compounds and lighting stimuli on $L$. tricolor-pollinator interaction. In addition, it is necessary to evaluate how this translates into plant fitness, i.e., seed production and germination rate, to examine the complete impact of floral damage on male/female reproductive success by a reduction in pollinator service.

\section{ACKNOWLEDGEMENTS}

We thank L. Flores for insect species identification and Y. Gutiérrez for artwork of $L$. tricolor. Financial support was obtained from the following grants: PSD-66, VID I 09/07-2, ACT 34-2006.

\section{REFERENCES}

Aizen, M.A. \& E. Raffaele. 1996. Nectar production and pollination in Alstroemeria aurea: responses to level and pattern of flowering shoot defoliation. Oikos 76(2): 312322.

Botto-Mahan, C. \& M. Ojeda-CAmacho. 2000. The importance of floral damage for pollinator visitation in Alstroemeria 
ligtu L. Revista Chilena de Entomología 26: 73-76.

Colwell, R.K. 2009. EstimateS: Statistical estimation of species richness and shared species from samples, version 8.2.0. URL: http://viceroy.eeb.uconn.edu/EstimateS. Viewed: January 10, 2011.

Di Castri, F. 1968. Esquisse écologique du Chili. In: C. Delamare Deboutteville \& T. Rapoport (eds.), Biologie de l'Amérique austral, pp. 7-52. Edition du Centre National de la Recherche Scientifique, Paris, France.

Dudareva, N., J.C.D'Auria, K.H.Nam, R.A. Raguso \& E.Pichersky. 1998. Acetyl -CoA: benzylalcohol acetyltransferase- an enzyme involved in floral scent production in Clarkia breweri. The Plant Journal 14(3): 297-304.

Dyer, A.G. \& L. ChittKa. 2004a. Biological significance of distinguishing between similar colours in spectrally variable illumination: bumblebees (Bombus terrestris) as a case study. Journal of Comparative Physiology A 190(2): 105-114.

Dyer, A.G. \& L. ChittKa. 2004b. Fine colour discrimination requires differential conditioning in bumblebees. Naturwissenschaften 91(5): 224-227.

FAegri, K. \& L. VAN DER PIJL. 1979. The principles of pollination ecology. Pergamon Press, New York. 244 pp.

Galen, C. \& J. Cuba. 2001. Down the tube: pollinators, predators, and the evolution of flower shape in the Alpine sky pilot, Polemonium viscosum. Evolution 55(10): 1963-1971.

Gómez, J.M. \& F. Perfectti. 2009. Diversidad de Polinizadores, generalización ecológica y conservación de plantas. En R. Medel, M. Aizen \& R. Zamora (eds.), Ecología y Evolución de Interacciones Planta-Animal, pp 62-76. Editorial Universitaria, Santiago, Chile.

Gotelli, N.J. \& R.K Colwell. 2001. Quantifying biodiversity, procedures and pitfalls in the measurement and comparison of species richness. Ecology Letters 4(4): 379-391.

Hofmann, A. 1998. Flora Silvestre de Chile: zona central, $4^{\text {th }}$ edn. Ediciones Fundación Claudio Gay, Santiago. 254 pp.

Karban, R. \& S.Y. Strauss. 1993. Effects of herbivores on growth and reproduction of their perennial host, Erigeron glaucus. Ecology 74(1): 39-46.

KRUPNICK, G.A. \& A.E. WEIss. 1999. The effect of floral herbivores on male and female reproductive success in Isomeris arborea. Ecology 80(1): 135-149.

Krupnick, G.A., A.E. Weis \& D.R. Campbell. 1999. The consequences of floral herbivory for pollinator service to Isomeris arborea. Ecology 80: 125-134.

LeAvitt, H. \& I.C. Robertson. 2006. Petal herbivory by chrysomelid beetles (Phyllotreta sp.) is detrimental to pollination and seed production in Lepidium papilliferum (Brassicaceae). Ecological Entomology 31(6): 657-660.
Lehtila, K. \& S.Y. Strauss. 1997. Leaf damage by herbivores affects attractiveness to pollinators in wild radish, Raphanus raphanistrum. Oecologia 111(3): 396-403.

Luebert, F. \& P. Pliscoff. 2006. Sinopsis bioclimática y vegetacional de Chile. Editorial Universitaria, Santiago. 316 pp.

Marquis, R.J. 1992. The selective impact of herbivores. In: R.S. Fritz \& E.L. Simms (eds.), Plant resistance to herbivores and pathogens: ecology, evolution and genetics, pp 301325. University of Chicago Press, Chicago, Illinois, USA.

MEdEL, R. \& J. NATTERO. 2009. Selección mediada por polinizadores sobre el fenotipo floral: examinando causas y blancos de selección natural. In: R. Medel, M. Aizen \& R. Zamora (eds.), Ecología y Evolución de Interacciones PlantaAnimal, pp 77-94. Editorial Universitaria, Santiago, Chile.

Morgan, M.T. \& J.K. Conner. 2001. Using genetic markers to directly estimate male selection gradients. Evolution 55(2): 272-281.

Mothershead, K. \& R.J. Marquis. 2000. Fitness impacts of herbivory through indirect effects on plant-pollinator interactions in Oenothera macrocarpa. Ecology 81(1): 3040.

MurawsKi, D.A. 1987. Floral resource variation, pollinator response, and potential pollen flow in Psiguria warscewiczii. Ecology 68(5): 1273-1282.

Raguso, R.A. \& E. Pichersky. 1995. Floral volatiles from Clarkia breweri and C. concinna (Onagraceae): recent evolution of floral scent and moth pollination. Plant Systematics and Evolution 194(1-2): 55-67.

SÁnchez-Lafuente, A.M. 2007. Corolla herbivory, pollination success and fruit predation in complex flowers: an experimental study with Linaria lilacina (Scrophulariaceae). Annals of Botany 99(2): 355-364.

Sokal, R.R. \& F.J. RohlF. 1995. Biometry. The principles and practice of statistics in biological research, $3^{\text {rd }}$ edn. W.H. Freeman and Co., New York. 887 pp.

Strauss, S.Y. 1997. Floral characters link herbivores, pollinators, and plant fitness. Ecology 78(6):1640-1645.

Strauss, S.Y. \& W.S. Armbruster. 1997. Linking herbivory and pollination new perspectives on plant and animal ecology and evolution. Ecology 78(6): 1617-1618.

Strauss, S.Y., J.K. Conner \& S.L. Rush. 1996. Foliar herbivory affects floral characters and plant attractiveness to pollinators: implications for male and female plant fitness. American Naturalist 147(6): 1098-1107.

Vorobyev, M., R. Brandt, D. Peitsch, S.B. Laughlin \& R. Menzel. 2001. Colour thresholds and receptors noise: behavior and physiology compared. Vision Research 41(5): 639-653.

Recibido: 25.03.11

Aceptado: 21.06.11 